\title{
Gene Expression of Heat Shock Protein (hsp q • ) Using RT-PCR for Local Isolate of Salmonella
}

\author{
Marwa Mohseen, Abdul Kareem A.AL-Kazazi and Ghazi M. Aziz \\ Department of Biotechnology, Collage of Science, University of Baghdad, Baghdad-Iraq.
}

\begin{abstract}
Six bacterial isolate were obtained for the genus Salmonella from the central health laboratory ministry of health Baghdad. Then these isolated were identified serologically by antisera test, from statins serum Institut (SSI) using the agglutination reaction (Antigen-antibody complex). The hsp 9 . gene was identified for the studied isolates by specific primers for gene amplification using PCR technique to include nucleotide sequence up and down stream gene. Results of electrophoresis on agarose gel revealed that the approximate size of the gene is about $17 / \mathrm{bp}$. The intensity of gene expression hsp 9 . for Salmonella Typhimurium measured by CT when the bacterial isolate was exposed to different temperatures $\left(\Gamma_{\cdot}, \Sigma_{\cdot}, \Sigma_{0,0}\right.$, and $0^{00}{ }^{\circ} \mathrm{C}$ using qRT-PCR result showed a regular increasing of gene expression with temperature, untile a maximum intensity observed at 0 . ${ }^{\circ} \mathrm{C}$. However the intensity at $00^{\circ} \mathrm{C}$ was statistically insignificant. The impact of UV light at $\mathrm{rr} \cdot \mathrm{nm}$ on gene expression for hsp 9 . on the Salmonella Typhimurium has been also studied and the results showed significant increase in the gene expression, compared to the normal growth temperature and to the internal positive control(Reference gene) $17_{\text {sRNA. }}$
\end{abstract}

Keywords: hsp $9 \cdot$. SPI. Salmonella serovars.

\section{Introduction}

Salmonella typhi is an important intracellular pathogen. Among the more than $r$, r. closely-related Salmonella serovars bacteria recognized, $S$. typhi is the only one that is pathogenic exclusively for humans, in whom it causes typhoid or enteric fever ['].

The genome of $S$. typhi is approximately ${ }^{\circ}$ million base pairs (bp) long and codes for some $\{, \ldots$ genes of which more than $r \cdots$ are functionally inactive. Different strains may also harbor extrachromosomal DNA in the form of plasmids which usually carry virulence or antibiotic resistance genes. The genes for virulence factors cluster in pathogenicity islands (PI) is integrated in to the bacterial chromosome. Non-pathogenic related species of Salmonella do not have PIs. PI genes expression is generally limited to specific host compartments $[\boldsymbol{r}]$.

The genetic control of Salmonella virulence is not fully known. However, both plasmid and chromosomal genes are involved. Many of the virulence genes of S. enteric are located on pathogenicity islands of the chromosomes, referred to as 'Salmonella pathogenicity islands' (SPI).

These genes are believed to have been acquired by Salmonella from other bacterial species through horizontal gene transfer [ $\left.{ }^{r}\right]$. Many efforts have been made to find effective vaccines against Salmonella infections, especially in cattle and poultry but also in swine. However, due to the complicated pathogenesis of Salmonella infection, no significant breakthrough has been achieved [₹]. Vaccines to control Salmonella infections, especially inactivated vaccines, are in use all over the world, Increasing numbers of live vaccines have been developed but most of them are not yet authorised.

Vaccination can play an important role in intervening against Salmonella in highprevalence herds $\left[^{\circ}\right]$. HSPs are classified into different families on the basis of their apparent molecular size, structure and function. Those families include HSP ' $\cdots$ and higher molecular

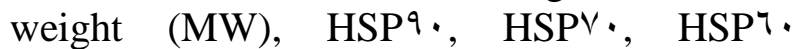
(chaperonin) and small HSP [־]. As already presented, HSPs promise to be a suitable vaccine candidate for use in humans because of their ability to induce a memory T-cell response and having the ability to induce strong immune response even in the absence of adjuvants. Another important feature that HSPs share is that they can directly activate cytotoxic T-lymphocytes without the assistance of $\mathrm{T}$ helper cells, which might be 
very useful in eliciting immune response even in immunocompromised individuals $[\mathrm{V}]$.

There are a number of techniques used to evaluate the amount of mRNA expression including Northern Blotting, cDNA arrays, in situ hybridization, RNase protection assays, and reverse transcription polymerase chain reaction (qRT-PCR) $\left.{ }^{\wedge}\right]$. Reverse transcription along with the polymerase chain reaction has proven to be a powerful method to quantify gene expression [9]. Real-time polymerase chain reaction (qRT-PCR) is rapidly becoming the new method for determining mRNA expression due to its capacity to use up to 1... times less RNA than other knows methods $[1 \cdot, 11]$.

\section{Aims of Study}

The aims of this study were detecting the hsp 9 . (HtpG) gene by amplifying it using the PCR technique from three isolate of salmonella: in addition the effect of some stress factors such as different temperature and ultraviolet ray and detecting the amount of expression by using qRT-PCR technique. The steps to achive the aim were:

l-collection of the local isolate belong to the genus of salmonella from the Central Health Laboratory and the isolates identification was repeated using same methods.

r-using of specific primer for detection of heat shock protein (hsp $\left.q^{\cdot}\right)$ gene by means of PCR technique.

r-DNA extraction from isolates under study with the installation of high purity optimum conditions for detection of $(\mathrm{HSP} \cdot)$ gene expression using qRT-PCR technique.

₹-Study the effect of some stress factors on the gene expression including the temperature at $\left({ }^{\circ} \circ{ }^{\circ} \mathrm{C}, \varepsilon \cdot{ }^{\circ} \mathrm{C}, \leqslant 0{ }^{\circ} \mathrm{C}, 0^{0} \cdot{ }^{\circ} \mathrm{C}\right.$ and $00{ }^{\circ} \mathrm{C}$ ) and UV ray.

\section{Materials and Methods}

\section{Bacterial isolates, Media and Chemicals}

Bacteria lisolates used in this study included S. typhymurium, S. typhi, S. enteriadis. Salmonella isolates were obtained from health laboratories diagnosed on the XLD and S-S agar, which appeared as black colony. The isolates of Salmonella were diagnosed in the health laboratories by the antisera from statins Serum Institute (SSI) and by using this test forms Antigen-antibody complexes (agglutination). Salmonella typhimurium used in RNA extraction for quantitative ereal time PCR were grown in ${ }^{\circ} \mathrm{ml}$ of BHI-broth (Bioneer, Company) for ishrs.

\section{DNA Extraction}

The growth of bacterial isolates S. typhimurium, S.typhi, S.enterdia by incubation for $1 / \mathrm{hrs}$ in BHI broth for extraction DNA using Exiprep TM 17 plus to determine the gene Hsp 9 . (HtpG). The cell pellet consisted of bacterial isolates after growing and centrifugation for ${ }^{\circ} \mathrm{min}$ at ro ${ }^{\circ}$ Cresuspend (up to $\mid * 1 \cdot{ }^{q}$ cells) in $r \cdots$ ul of resuspension buffer. Puncture the cartridge with the hole-punch tool to correspond with the sample number that used. The buffer cartridge was placed, elution tube rack and disposable tip rack on the setup tray, then the steps were completed by the device.

\section{Amplification of HSPG 9 • gene}

Primers: The primers were selected according to Osman etal., $\left(r_{\cdot} \mid r\right)$. These primers amplified the HSPG ${ }^{q}$ - gene the sequences of PCR primers as follows:

(HSP 9 . F: ०'-

TACGTTGACCATTGCCGATA - ${ }^{\prime}$

HSP ${ }^{q} \cdot \mathrm{R}^{\circ}{ }^{\prime}$ AGAAGCCTACGCCAAACTGA I I IRNAF:०'CTGTCGTCAGCTCGTGTTG $T^{\prime \prime}$ I ISRNA R: ०'-

CGTAAGGGCCATGATGACTT ${ }^{\prime \prime}$ )

All primers were supplied by Alpha DNA Company, Canada.

\section{Conventional PCR (reactions and programs) for detecting the gene hsp $q$. (HtpG):}

Using $r \odot \mu \mathrm{L}$ of PCR reaction, $1,0 \mu \mathrm{L}$ DNA template ( $\cdots n g / \mu \mathrm{L})$ was amplified using I $r, 0 \mu \mathrm{L}$ of Go Taq ${ }^{\circledR}$ green master mix $r \mathrm{X}$ (Promega, USA) and $\cdot, r \mu \mathrm{L}$ of each primer of RM $|V|$ primers $(1 \cdot \mathrm{pmol} / \mu \mathrm{L})$ or $\cdot, 0 \mu \mathrm{L}$ of each primer of $\mathrm{P}{ }^{\mathrm{o}} \mathrm{S}$ primers $(1 \cdot \mathrm{pmol} / \mu \mathrm{L})$, up to the final volume ro $\mu \mathrm{L}$ with nucleases free water. PCR programs were set on Lab net International thermal-cycler (Multigene TM Gradient Thermal Cycler, Korea); Table (1) describes the conditions of these programs $[\mathrm{I} Y \mathrm{r}$. 
Table (1)

The PCR programs conditions.

\begin{tabular}{|l||c||c|}
\hline \multicolumn{1}{|c||}{ Steps } & $\begin{array}{c}\text { Temperature } \\
\left({ }^{\circ} \mathrm{C}\right)\end{array}$ & $\begin{array}{c}\text { Time } \\
(\text { min })\end{array}$ \\
\hline \hline Initial denaturation & $9 \varepsilon$ & 0 \\
\hline \hline Denaturation & $9 \varepsilon$ & 1 \\
\hline Annealing & $T r$ & 1 \\
\hline Extension & $V Y$ & 1 \\
\hline Final Extension & $V Y$ & $1 \cdot$ \\
\hline
\end{tabular}

No. of cycles $=\leqslant$. cycles between initial denaturation and final extension.

\section{Agarose gel electrophoresis}

The PCR products and $1 \cdots$ bp DNA ladder bands (Promega, USA) were separated using $r \%$ agarose gel electrophoresis, then stained with ethidium bromide and visualized under the ultraviolet light $(r Y \cdot n m)[1 r]$. The molecular size of PCR products were about $171 \mathrm{bp}$ for HSPq.

\section{RNA Extraction and RT-PCR}

After growing the $S$. typhimurium isolate in BHI by incubation overnight to determine the amount of gene expression,total RNA was extracted from $S$. typhimurium using RNA isolation kit according to the manufacturer's instructions. The absorbencies of RNA samples were checked at $r \uparrow \cdot$ and $r \wedge \cdot n m$ for determination of sample concentration and purity using Nano drop. The ratio of A $r$ r. to $A Y \wedge$. values is a measure of RNA purity [ $1 \leqslant]$. The RNA concentration was adjusted to 1..ng/ $\mu$ l. Total RNA was reverse-transcribed to cDNA using Super Script II reverse transcriptase (ACCU POWER Roket RT-PCR PreMIX).Total RNA $(1 \cdot \mu \mathrm{g})$ were mixed with i ul of each primer and the total volume was made up to $r \cdot$ ul by DEPC.

\section{Gradient PCR for cDNA synthesis:}

Each reaction mixture included 1. PCR sample mixtures and each sample was subjected to a different annealing temperature following a gradient temperature to determined the proper annealing temperature for each primer site to cDNA synthesis. Total RNA was reverse transcribed to cDNA using (ACCU POWER Roket RT-PCR PreMIX). Total RNA ( $|-| r \mu l)$ was mixed with $\mid$ ul of each primer and the total volume was made up to $r \cdot u l$ by DEPC. The professional gradient thermal cycler and the program was adjusted that as follows: 'cycle at $90^{\circ} \mathrm{C}$ for ${ }^{\circ}$ minute followed by heating to $90^{\circ} \mathrm{C}$ for $r \cdot$ seconds, $0 .-7 r^{\circ} \mathrm{C}$ for $r \cdot \sec$ and $V r^{\circ} \mathrm{C}$ for $1 \mathrm{~min}, 0 \cdot-$ $7 .{ }^{\circ} \mathrm{C}$ for $r$. sec. These three steps were repeated for to cycles followed by final extension to $\mathrm{Vr}^{\circ} \mathrm{C}$ for 1 min for 1 cycle. The best annealing temperature was determined after visualizing the product on agarose gel.

\section{Real-time PCR (reactions and program)}

The Real-Time PCR reaction was performed using Accu Power Green Star qPCR PreMix Kit (Bioneer-Korea). This premix pellet containing all required components for qPCR reaction with the exception of the DNA template and primers. Furthermore, this pre-mix containing SYBR Green dyes for monitoring the amplification process. For each reaction,, $0 \mu \mathrm{L}$ of each $\mathrm{HSP}^{q} \cdot$ primers (1. $\mathrm{pmol} / \mu \mathrm{L})$ and $1,0 \mu \mathrm{L}$ of DNA $(1 \cdots \mathrm{ng} / \mu \mathrm{L})$ were added. The final volume was adjusted to $r$. $\mu \mathrm{L}$ with DEPC-distilled water. The RealTime PCR program conditions for HSP 9. detection were carried out, initial denaturation, at $90^{\circ} \mathrm{C}$ for $0 \min (1$ cycle), followed by $\leqslant 0$ cycles of denaturation: at $90^{\circ} \mathrm{C}$ for $r \cdot \sec$, annealing: at ${ }^{7 r}{ }^{\circ} \mathrm{C}$ for $r \cdot \sec$, extension: at $\checkmark \cdot{ }^{\circ} \mathrm{C}$ for $r \cdot \sec$ and scan the fluorescent of SYBR Green dye. Subsequently, the PCR products exposed to melt by increasing $1^{\circ} \mathrm{C}$ every $r$ sec starting from $r$. up to ${ }^{90}{ }^{\circ} \mathrm{C}$ to making sure that products specificity All PCR runs, conventional PCR and Real-Time PCR, included negative and positive control samples. To detect any contamination, negative control reaction was set in each PCR experiment, a negative control reaction containing all components of the reaction without DNA template. On the other hand, a positive control was prepared to determine the effectiveness of the conditions of PCR reaction and program. A positive control reaction containing all components of the reaction with DNA template of standard sample.

\section{Results and Discussion \\ Identification of Salmonella isolates}

Salmonella Isolates were obtained from centralhealth laboratory and diagnosed in the first stepon the XLD and S-S agar, which 
appeared as black colony. Then the diagnosis of isolates were completed by the antisera from statins serum Institute (SSI) using the agglutination reaction (Antigen-antibody complex).

To detect gene hsp ${ }^{q}$. DNA extraction from (S. typhimurium, $S$. typhi and $S$. Enterdis). by using the Exiprep TM 17 plus Bacteria Genomic DNA kit (Bioneer company). This kit suitable for the extraction of genomic DNA from gram negative bacteria, gram positive bacteria and yeast. Gram positive bacteria and yeast need enzymatic digestion step with lysozyme to make spheroplast. Results showed high DNA concentration with $\mathrm{\circ} \cdot \mathrm{ng} / \mu \mathrm{l}, \leqslant q \cdot \mathrm{ng} / \mu \mathrm{l}$ and rvo ng/ $\mu \mathrm{l}$ for S. Typhimurium, S.typhi and S.Enterdis respectively. The high purity was determined by using the Nanodrope-ND $1 \cdots$. The absorbance at $r \uparrow . / r \wedge$, gave an optical density ratio of 1,70, 1, vo, and 1,91 respectively. Several amplification methods such as Uniplex PCR, Nested PCR and Real time PCR were used for detection of bacterial such as Salmonella species [10].

All tested samples of PCR showed positive results (band with size $17 / \mathrm{bp}$ ), for HSP ${ }^{9}$. in (Fig.( (1)), this result is similar to those of previously published which used different species specific genes to detect gene expression in different Salmonella spp.[17]. Also to confirm the DNA integrity to be used in PCR experiments.

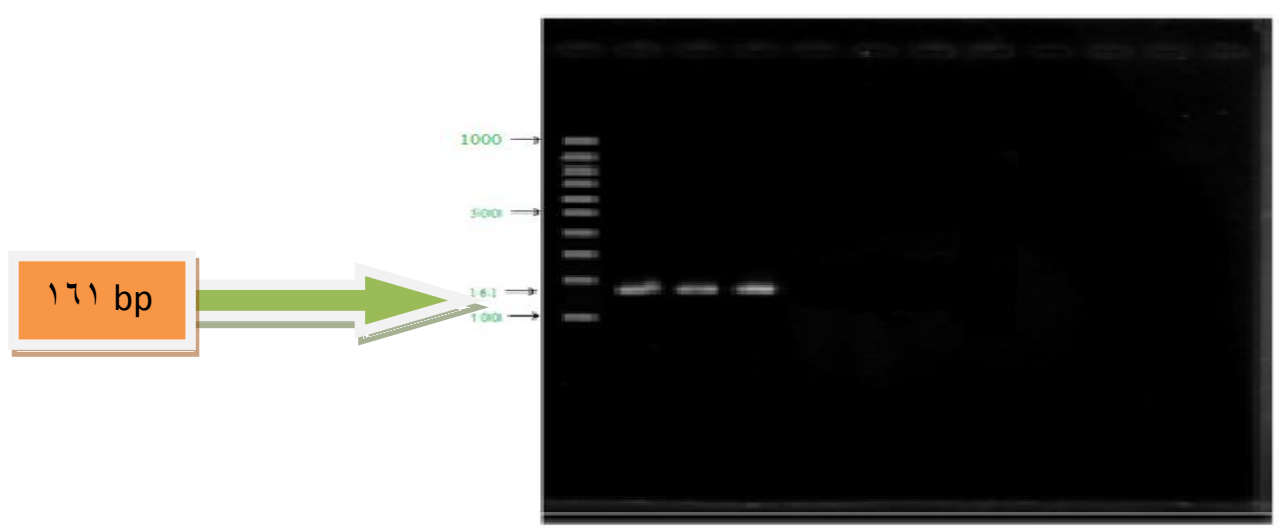

Fig. (1) PCR amplification of HSPG $9 \cdot$. PCR products run in ( $\%$ ) agarose gel using $\cdot$, OX TBE -V/cm for Thrs. Lanes M: ' ’ bp DNA ladder; Lane ': S. typhimurium, Lane r:S.Enteridis, Lane r: S.enteridis.

\section{Heat Shock Protein $9 \cdot$ Expression Profiling}

Using the Quantitative Real time PCR, Fig. $(r)$ of the HSPq • in S. typhimurium revealed a higher expression after exposure to different temperature at 0 . c compared to ro, $\varepsilon \cdot, \leqslant 0$, while the Duucan analysis showed in Fig. $(r)$ by $r q, \cdot \varepsilon \pm \cdot, 0 \vee, r \cdot, \tau \cdot \pm \cdot, V), r, 1, \wedge \vee \pm$ I, $r$ rand $r Y, T V \pm 1, \Sigma 1$ that showed in Table $(Y)$.

\section{Table ( $r)$}

Quantitative analysis of the relative changes in heat shock protein $9 \cdot\left(\mathrm{HSP}^{9} \cdot\right)$ expression levels using real-time quantitative PCR among different temperature of Salmonella typhimurium.

\begin{tabular}{|c|c|c|}
\hline \multirow{2}{*}{$\begin{array}{c}\text { Temperature } \\
\left({ }^{\circ} \mathrm{C}\right)\end{array}$} & \multicolumn{2}{|c|}{ CT Value (Mean $\pm S D) *$} \\
\hline & Treated & Controls \\
\hline ro & $r_{q}, \varepsilon_{ \pm} \cdot, 0 V^{B}$ & $1 V, 9 q_{ \pm} \cdot, 1 r^{C}$ \\
\hline$\varepsilon$. & $\Gamma \cdot, \tau \cdot \pm \cdot, \vee \backslash \mathrm{AB}$ & $\mid V, \| \pm \cdot, \varepsilon V^{C}$ \\
\hline «o & $\Gamma_{1}, \wedge V_{ \pm} 1, r r_{A}$ & $I V, r q_{ \pm} \cdot, 0 \leqslant B C$ \\
\hline 0 . & $\bar{r}, T V_{ \pm 1}, \varepsilon \backslash \mathrm{A}$ & $1 \wedge, 77 \pm \cdot, \cdot 9 B$ \\
\hline 00 & $\overline{Y r, \Sigma \cdot \pm \cdot, Y \circ A}$ & $r_{r}, r_{ \pm} \cdot, 19 \mathrm{~A}$ \\
\hline
\end{tabular}


Journal of Al-Nahrain University Science

Gene-expression analysis is increasingly important in many fields of biological research. Understanding patterns of expressed genes is expected to provide insight into complex regulatory net works and will most probably lead to the identification of genes relevant to new biological processes, or implicated in disease. RT-PCR provides the simultaneous measurement of gene expression in many different samples for a limited number of genes and is especially suitable when only a small number of cells are available [10].

Fig. $(r)$ shows the melt-curve of the products specificity since SYBR Green Dye may bind to double strand DNA such as
Vol. IV (\&), December, Y. I\&, pp. $10 \leqslant-171$

specific/non-specific PCR products or primerdimmers [17]. If the PCR products were specified, they would have the same length; thus the melt peaks of these products were at the same temperature while the non-specific PCR products have different temperature depending on the product's length and other factors. These results came to confirm the results of conventional PCR and to detect the SYBR green kit effectiveness to be used in the future for routine work in detecting $\mathrm{HtpG}$ gene (hsp 9 •). This method is a rapid process for gene expression, where it gives a reliable result within a few hours without the need for agarose gel electrophoresis analysis [ $\mathrm{l}$ V].

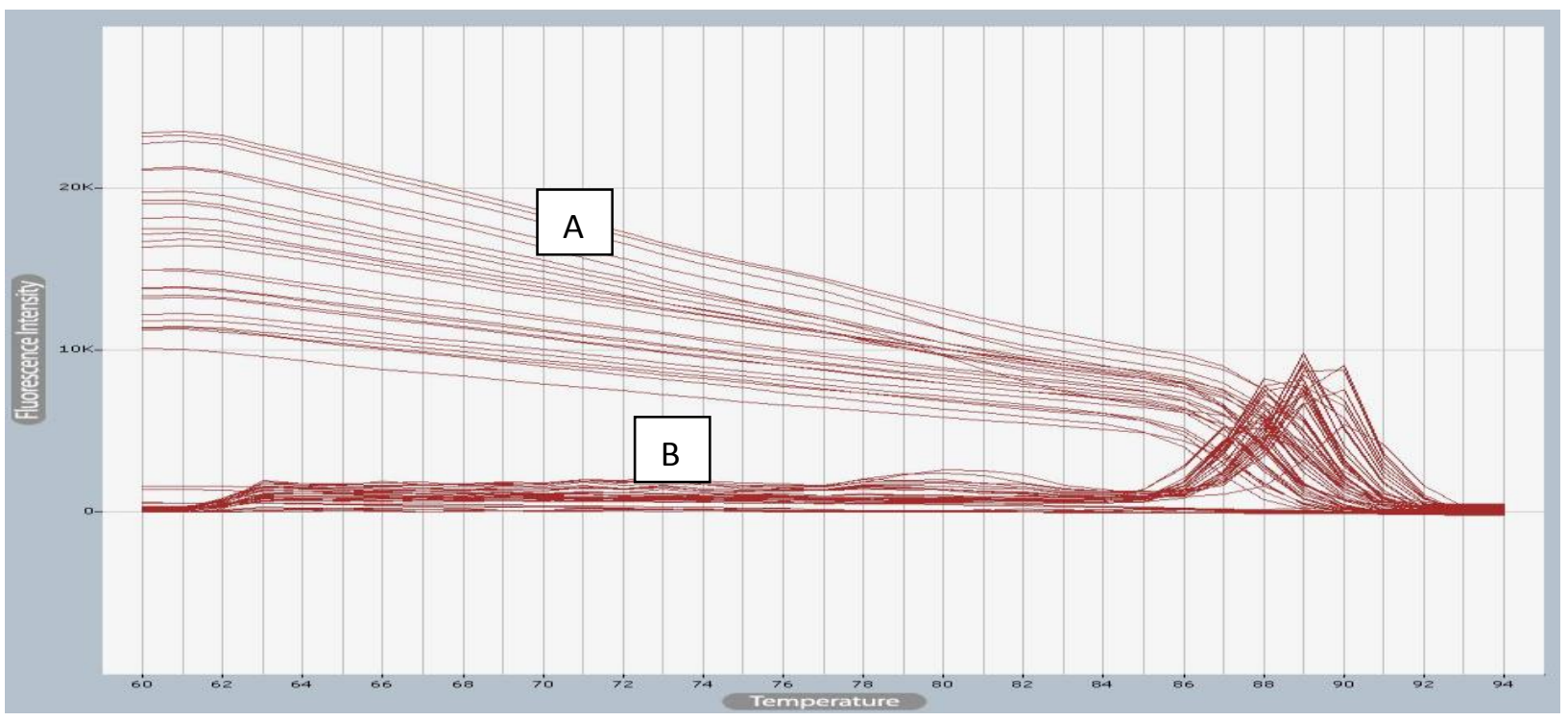

Fig.(") Graphs(A) of (hsp १•) gene expression of real time PCR amplification-curve and (B) melt-curve of 1 isRNA and stright curve negative control.

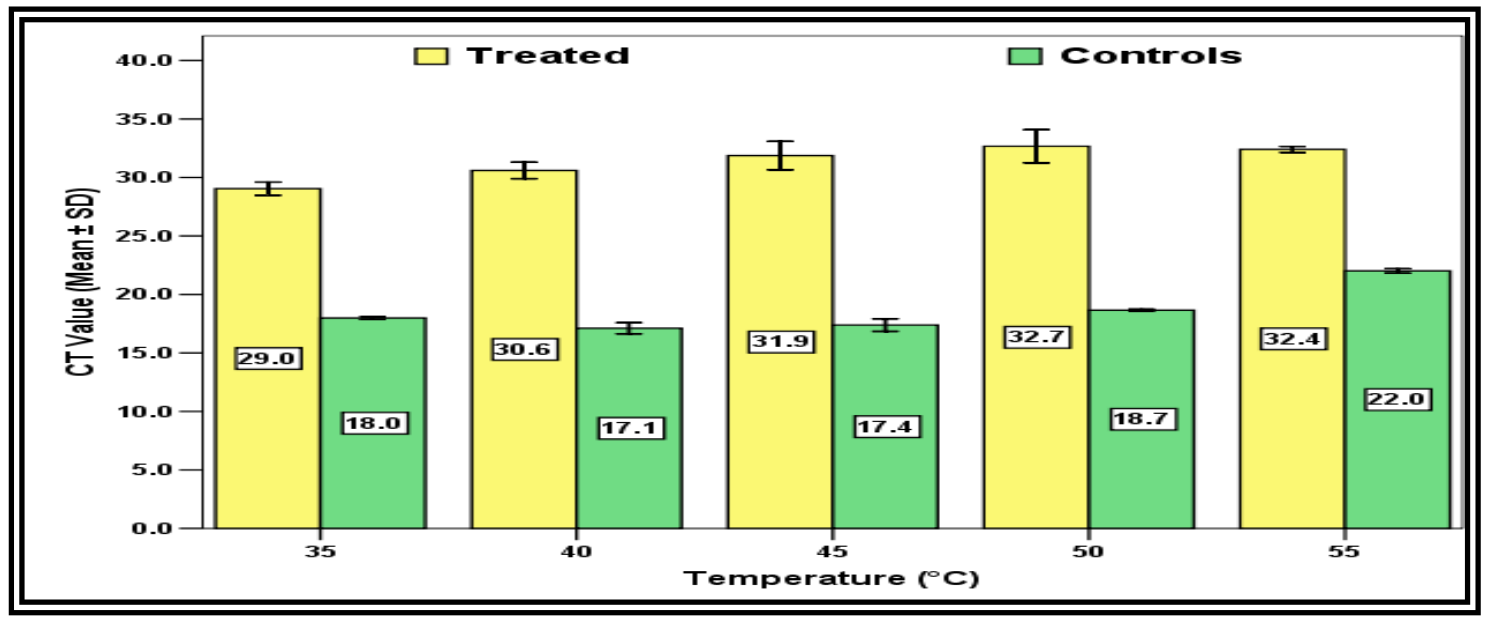

Fig.( (") Relative gene expression of the treated and control in S.typhimurium for all treatment with temperature for detection of gene expression.

Yellow column: treated sample Hsp ${ }^{q}$.

Green column: control is $\mathrm{RNA}$. 
mRNA expression profiling quantification requires normalization and several variables need to be controlled in gene expression analysis [ ${ }^{\wedge} \wedge$ ].In the present study, QRT-PCR was used to examine differential expression profiles of some of NCBI identified proteins that are found to correlate virulence among $S$. enteritis disserovars in comparison to 17 sRNA as reference gene. QRT-PCR results obtained from measuring the differences in expression level among Salmonella pathogenicity [19]. This result gives a strong evidence of the specificity of these proteins to $S$. gallinarum which could increase the speculation of its role in host over adaptation and/or virulence among the poultry species. This coincides with the previous results $[r \cdot]$.

The Salmonella (SPI) 1 and $r$ are two major virulence determinants of $S$. entericaas they encode type III secretion systems (TIIISS) that form syringe-like organelles on the surface of Gram-negative bacteria and enable the injection of effector proteins directly into the cytosol of eukaryotic cells [ri].

\section{The effect of UV on the gene expression of S.typhimurium.}

After exposure the of S. typhimurium broth to $U V(r r \cdot n m)$ for $1 \cdot$ min then extraction RNA by using the Gentrapuregen cell kit showed high RNA concentration with $\leqslant r \cdot n g / \mu l$, with high purity which was determined by using the Nanodrope-ND $1 \cdots$. The absorbance at $r \uparrow \cdot / r \wedge \cdot$ gave an optical density ratio $(1, \wedge)$ then converted to cDNA by Super Script II reverse transcriptase (Invitrogen). Then Run in RT-PCR the Ct average was 1,11 compare with the average $\mathrm{Ct}$ value of the internal positive control (reference gene) the average $\mathrm{Ct}$ value $1 \leqslant, \varepsilon \wedge$. This result mean $\mathrm{UV}$ induce hsp 9 . (HtpG) gene and lead to increase gene expression compared to the normal growth temperature and the internal positive control. Fig. $\left({ }^{\top}\right)$ shows the gene expression after exposure UV.

While the Duncan analysis for gene expression after exposure $S$. typhimurium suspension to $\mathrm{UV}$ the result of $\mathrm{Ct}$ value $r, 1 r \pm r, 11$ and the internal positive control $\mid \varepsilon, \varepsilon \vee \pm \cdot, 1 \wedge$ that showed in Table ( $r)$ Fig. $(\varepsilon)$ showed the results differences of $\mathrm{HspG} q$. gene expression levels between UV treatment and ${ }^{\mathrm{O}}{ }^{\circ} \mathrm{C}$ treatment showed the HSPG ${ }^{9}$ gene expression levels difference between UV and ro ${ }^{\circ} \mathrm{C}$. this result mean gene hsp ${ }^{q}$. responds to UV stress and lead to increasing the level of gene expression of gene hsp ${ }^{q}$. (HtpG).

Table ( $"$ )

Quantitative analysis of the relative changes in heat shock protein ${ }^{q} \cdot\left(H_{S P} q^{\circ}\right)$ expression levels using real-time quantitative PCR between ${ }^{\circ}{ }^{\circ} \mathrm{C}$ temperature and $U V$ of Salmonella Typhimurium.

\begin{tabular}{|c|c|c|}
\hline \multirow{2}{*}{$\begin{array}{c}\text { Temperature } \\
\left({ }^{\circ} \mathrm{C}\right)\end{array}$} & \multicolumn{2}{|c|}{ CT Value $($ Mean $\pm S D) *$} \\
\hline & Treated & Controls \\
\hline ro & $r q, \cdot \varepsilon_{ \pm \cdot, 0 V}$ & $\left.1 v, 9 q_{ \pm \cdot}, 1\right\}$ \\
\hline$r o+U V$ & $r 1,1 r \pm r, 11$ & $1 \varepsilon, \varepsilon V_{ \pm \cdot}, 1 \wedge$ \\
\hline & N.S. & $\cdot, \cdot r$ \\
\hline
\end{tabular}

*Different letters: Significant difference $(P \leq \bullet, \bullet)$ between means of columns (Duncan test).

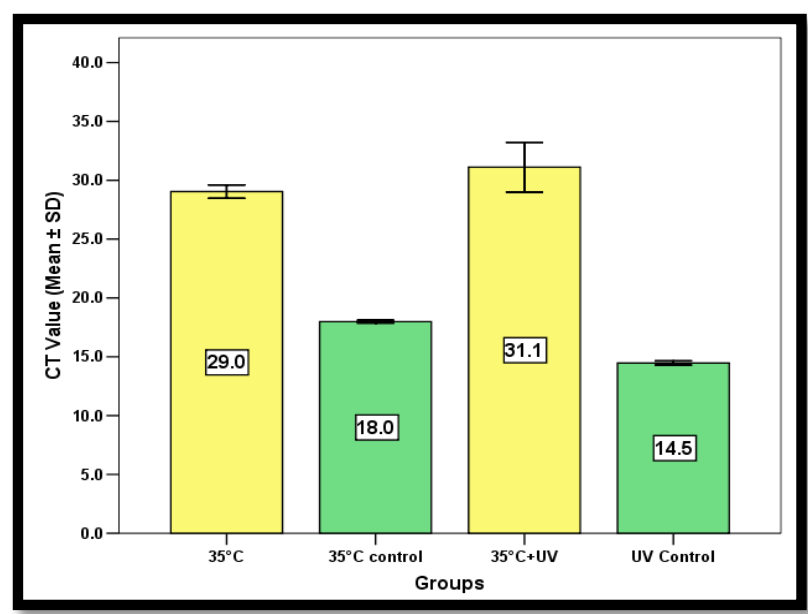

Fig. ( $)$ The relative gene expression between $U V$ exposure and control $\left(\right.$ at $\left.{ }^{\mu} \circ{ }^{\circ} \mathrm{C}\right)$.

Conclusions: Based on the results of the present study, the followings conclusions were made: Amplified Htp Ggene of S.typhimurium, S.typhi and S.enteridis have a molecular weight of approximately $171 \mathrm{bp}$ with $1 \ldots \%$ identity as compared with $\mathrm{HtpG}$ sequence database found in NCBI Gen Bank. Detection of gene expression (HSPq.) of $S$. Typhimurium by qRT-PCR and identified the gene expression induction with increasing of elevated temperature. Based on there result it was found that $0 .{ }^{\circ} \mathrm{C}$ was the best temperature for hsp $q$. gene expression. The same results was observed during exposure $S$. typhimurium 
to UV light at $r Y \cdot n m$ the expression of hsp ${ }^{q}$. gene was increased.

\section{References}

['] Lian Zhang, X., Jeza, V.T. and Pan, Q. Salmonella Typhi: from a Human Pathogen to a Vaccine Vector. Cellular Molecular Immunology. ${ }^{\circ}(r): 91-9 \vee, r \cdots \wedge$.

[r] Baker, S. and Dougan. G. The genome of Salmonella entericaserovar Typhi. Clin Infect Dis. \&0: rq_r r. r....

[ץ] Van Asten, A.J.A.M and van Dijk, J.E. Distribution of 'classic' virulence factors among Salmonella spp. FEMSImmunol.

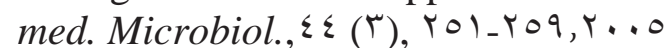

[₹] Chiu, C.H., Su, L. H., and Chu, C.Salmonella enterica serotype Choleraesuis epidemiology, pathogenesis, clinical disease, and treatment. Clin.

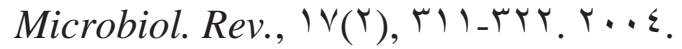

[0] Haesebrouck, F., Pasmans, F., Chiers, K., Maes, D., Ducatelle, R. and Decostère, A. Efficacy of vaccines against bacterial diseases in swine.Vet. Microbiol., '.. ( $\Gamma_{-}$

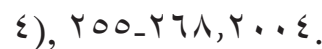

[`] Pathan, M.M., Latif, A., Das, H., Siddiquee, G.M. and Khan, M.J.Z. Heat Shock Proteins and their clinical Implications. Veterinary World. $r(1 Y): 00 \Lambda_{-}$ 7. Y. . .

[`] Paliwal, P.K., Bansal, A., Sagi, S.S.K. and Sairam, M. Intraperitoneal immunization of recombinant HSP $\mathrm{H}^{\mathrm{V}}$ (DnaK) of Salmonella Typhi induces a predominant $\mathrm{Th}^{r}$ response and protective immunity in mice against lethal Salmonella infection. Vaccine, $r q$ : rorr_tor9. Y. 11.

[^] Giulietti, A., Overbergh, L., Valckx, D., Decallonne, B., Bouillon, R., and Mathieu, C. An overview of real-time quantitative PCR: applications to quantify cytokine gene

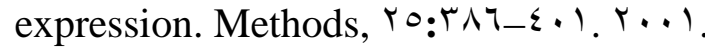

[9] Osman, K.M., Radwan, M.I., Zeinab, M.S., Bakry, M.A. and Hakim, A.S. Protein Expression Diversity amongst Different Serovars of Salmonella enteric Using Quantitative Real Time PCR Global Veterinaria, $\wedge(7)$ : 0 To_oVr. Y.I Y.

[1.]Bustin, S. A. Absolute quantification of mRNA using real-time reverse transcription polymerase chain reaction assays. J. Mol. Endocrinol, ro:1 $7 q_{-} 19$ r. r....
[1'] Hashimoto, M., P. C., Chen, M. W., Mitchell, D. E., Nikitopoulos, S. A., Soper, and Murphy M. C. Rapid PCR in a continuous flow device. Lab Chip. $\Sigma(\urcorner)$ : p.

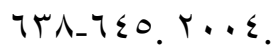

[I ${ }^{1}$ ] Mahmood, T., Safdar, W., Abbasi, B. H. and Nagvi, N. S. An overview on the small heat shock proteins. African Journal of Biotechnology, $9: 9 r \vee-9 \leqslant q . r \cdot 1 \cdot$.

[1T] Sambrook, J. and Russell, D.W. Molecular Cloning: A Laboratory Manual. rrd Edn., Cold Spring Harbor Laboratory Press, Cold Spring Harbor, New York. r... .

[ ${ }^{\prime}$ ] Chadfield, M.S., Brown, D.J., Aabo, S., Christensen, J.P. and Olsen, J.E. Comparison of intestinal invasion and macrophage response of Salmonella Gallinarum (SG) and other host-adapted Salmonella enteric serovars in the avian host. Vet. Microbiol., $\left.9 r_{\text {: }} \leqslant q_{-}\right\urcorner \varepsilon, r \ldots r$.

[10] John, M., McMenamy, M., Hjertner, B. and McNeilly, F.A. Uttenthal. Sensitive detection African swine fever virus using real-time PCR with a ${ }^{\circ}$ _ conjugated minor groove binder probe. Journal of Virological Methods $17 \wedge(Y \cdot 1 \cdot) 1 \leqslant 1-1 \leqslant 7 . Y \cdot 1 \cdot$.

[1 17 Hapfelmeier, S., Ehrbar, K., Stecher, B., Barthel, M., Kremer, M. and Hardt, W.D. Role of the Salmonella Pathogenicity Island 1 Effector Proteins SipA, SopB, SopE and SopE $r$ in Salmonella enteric Subspecies I Serovar Typhimurium Colitis in Streptomycin-Pretreated Mice. Infect.

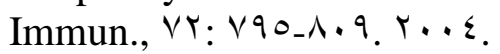

[ $\left.{ }^{\vee}\right]$ Vidhya, S.S., Ramanjini Gowda, P.H., Yogendra, K.N., Ningaraju,. M. and Salome, T. Detection of genetically modified cotton seeds using PCR and realtime PCR. Indian J. Biotechnol., 11: IV צ. |NI. Y.|Y.

[1^] Rizzi, A., Sorlini, C. and Daffonchio, D. Practicality of detection of Genetically Modified Organisms (GMOs) in food.

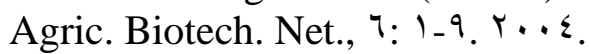

[19] Osman, K.M., Ali, M. M., Radwan, M.I., Kim, H.K. and Han, J. Comparative Proteomic analysis on Salmonella Gallinarum and Salmonella Enteritidis exploring proteins that may incorporate host 
adaptation in poultry. J. Proteomics, $\mathrm{V}$ : rAlO_rAYl. r...

$\left[r^{*}\right]$ Dieye, Y., Ameiss, K., Mellata, M. and Curtiss, R. The Salmonella Pathogenicity Island (SPI) contributes more than SPIr to the colonization of the chicken by Salmonella enterica serovar Typhimurium.

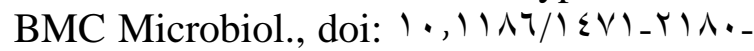
१_r. r... q.

[r)]Waterman, S.R. and Holden, D.W. Functions and effectors of the Salmonella pathogenicity island $r$ type III secretion system. Cell Microbiol., 0:0.1_011, Y... .

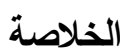

تم الحصول على 1 عزلات بكتيرية العائدة لجنس

salmonella بغداد. ثم بعد ذلك تشخيصها سيرولوجيا بواسطة

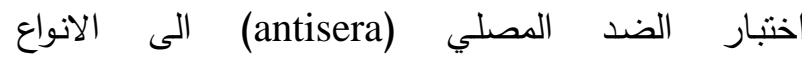
S.Typhimurium, S.typhi, S.Enteridis الصدمة الحرارية ( •HSP9) للعزلات تحت الدراسة باختيار بادئات متخصصة لتضخيم الجين المذكور باستخدام تقنية تفاعل تضاعف السلسلة (PCR) لتتضمن التتابعات النيوكليوتيدية الواقعة اعلى واسفل مجرى الجين. اظهرت نتائج الترحيل الكهربائي على هلام الاكاروز ان الحجم الجزيئي

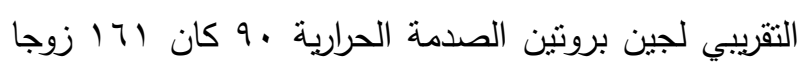
قاعديا.

تم تحديد شدة التعبير الجيني لجين . HSPq العائد

لعزلة S.Typhimurium مقاسا بتردد العتبة (CT) عند

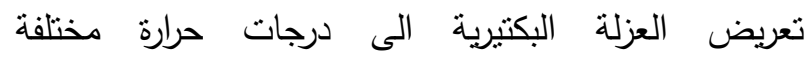

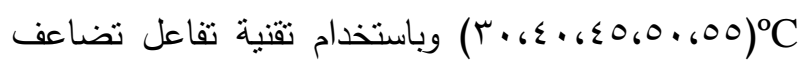
السلسة الكمي (qRT-PCR) اظهرت النتائج زيادة مضطردة لثدة التعبير الجيني منوافقة مع الزيادة بدرجات الحرارة وصولا

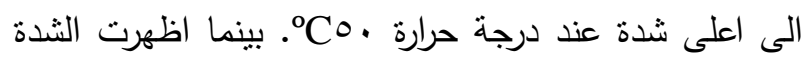
عند درجة حرارة C00 لميادة طفيفة غير معنوية احصائيا.

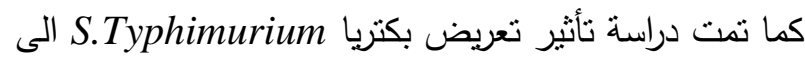

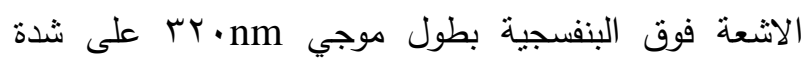

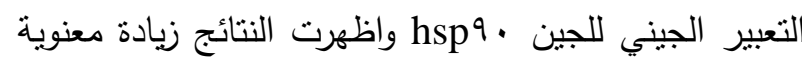
لثدة التعبير الجيني. 